\title{
Antarctic Science
}

http://journals.cambridge.org/ANS

Additional services for Antarctic Science:

Email alerts: Click here

Subscriptions: Click here

Commercial reprints: $\underline{\text { Click here }}$

Terms of use : $\underline{\text { Click here }}$

\section{Magnetic properties of Upper Quaternary sediments from the Scotia Sea, Antarctica}

Norman Hamilton and Carol J. Pudsey

Antarctic Science / Volume 13 / Issue 01 / March 2001, pp 61 - 66

DOI: 10.1017/S0954102001000098, Published online: 27 April 2004

Link to this article: http://journals.cambridge.org/abstract_S0954102001000098

How to cite this article:

Norman Hamilton and Carol J. Pudsey (2001). Magnetic properties of Upper Quaternary sediments from the Scotia Sea, Antarctica. Antarctic Science,13, pp 61-66 doi:10.1017/S0954102001000098

Request Permissions : $\underline{\text { Click here }}$ 


\title{
Magnetic properties of Upper Quaternary sediments from the Scotia Sea, Antarctica
}

\author{
NORMAN HAMILTON' and CAROL J. PUDSEY² \\ 'School of Ocean and Earth Science, University of Southampton, Southampton Oceanography Centre, Southampton SO14 $3 Z H$, UK \\ ${ }^{2}$ British Antarctic Survey, Natural Environment Research Council, High Cross, Madingley Road, Cambridge CB3 OET, UK
}

\begin{abstract}
Magnetic properties of bulk sediment samples taken from three cores from the Scotia Sea, Antarctica were determined using a fully-automated variable field translation balance. Fine-grained detrital magnetite is identified as the principal carrier of remanence in these Upper Quaternary sediments which were deposited under the influence of the Antarctic Circumpolar Current. Inferred magnetite grain-size is consistent with published bulk grain-size data for these cores. Pseudo-single domain grains characterize Holocene samples, and larger, multi-domain grains occur in glacial samples from two of the cores, whereas samples from the northernmost core site show dominantly multi-domain behaviour.
\end{abstract}

Received 17 August 2000, accepted 22 November 2000

Key words: environmental magnetic parameters, Quaternary, Scotia Sea, sediments

\section{Introduction}

Southern Ocean sediments are sensitive recorders of the state of glaciation of Antarctica. They preserve evidence of changes in sea ice cover, iceberg rafting, biological productivity and deep ocean circulation. Deep circulation has been studied using a variety of proxy measurements including stable isotopes as water mass tracers (Charles \& Fairbanks 1992), radiogenic isotopes and reworked microfossils as indicators of sediment redistribution (Burckle 1981, Frank et al. 1996), and grain size as an indicator of palaeocurrent strength (Pudsey 1992). In other areas of the ocean, environmental magnetic parameters are being developed as climate proxies (e.g. Stoner et al. 1995). Sagnotti et al. (1998) utilised the environmental magnetic record of glaciomarine sediments of the CIROS-1 core, McMurdo Sound, Antarctica to infer palaeoclimate during the Eocene/Oligocene boundary interval.

Composition and grain size of magnetic minerals in areas distant from continental margin sources provide a useful adjunct to bulk sediment texture and composition. This present study is the first to describe the environmental magnetic parameters of Scotia Sea sediments other than their bulk magnetic susceptibility which was previously reported by Pudsey \& Howe (1998).

The sediment samples used in this investigation were taken from two piston cores (PC29 and PC31) together with a Kasten core (KC64) obtained during cruises on the RRS Discovery (1987/88) and RRS James Clark Ross (1992/93), respectively. Core PC29 is located in the north-central part of the Scotia Sea and PC 31 is situated some $260 \mathrm{~km}$ to the southwest; the site of KC64 lies south of the North Scotia Ridge (Fig. I \& Table I).

Lithologically, the cores are composed of an upper biogenic unit which is dominantly a diatom ooze or foraminiferbearing diatom mud underlain by a terrigenous diatom mud unit (Pudsey \& Howe 1998). Some thin vitric ash layers, often preserved as smectitic alteration products, are also present (Moreton \& Smellie 1998). The unaltered ash layers can be identified by a magnetic susceptibility peak in downcore susceptibility records (Pudsey \& Howe 1998). Cores PC29 and PC3 1 also contain a lower biogenic unit of muddy diatom ooze and diatom mud. Within the dominantly terrigenous component of the sediments deposited during the Last Glacial Maximum at site KC64, Pudsey \& Howe (1998) reported magnetite as a prominent constituent of the fine-grained fraction.

Jordan \& Pudsey (1992) defined a local diatom stratigraphy for the Scotia Sea, extending back to approximately 60000 years. However, for PC29 and PC31, studies of radiolarian and palaeomagnetic stratigraphy (Jordan \& Pudsey 1992) indicate that sediment recovery in the base of these piston cores is no older than $c .30 \mathrm{ka}$. Both cores contain a dominant peak in the relative abundance of the radiolarian species Cycladophora davisiana which has been correlated with the Last Glacial Maximum at $18 \mathrm{ka}$. Evidence for the high sedimentation rates in these cores and their interglacial/glacial sedimentology is described by Pudsey \& Howe (1998). They demonstrated that the core locations are in depositional environments characterized by contourite sedimentation. The sediments record the fluctuating history of palaeoflow of the Antarctic Circumpolar Current during the late Quaternary. Hence, the remanence carriers may be strongly influenced by the nature of terrigenous and biogenic sediment supplied under the control of the Antarctic Circumpolar Current.

\section{Methods}

Magnetic parameters including high-temperature thermomagnetic properties, saturation isothermal remanence 


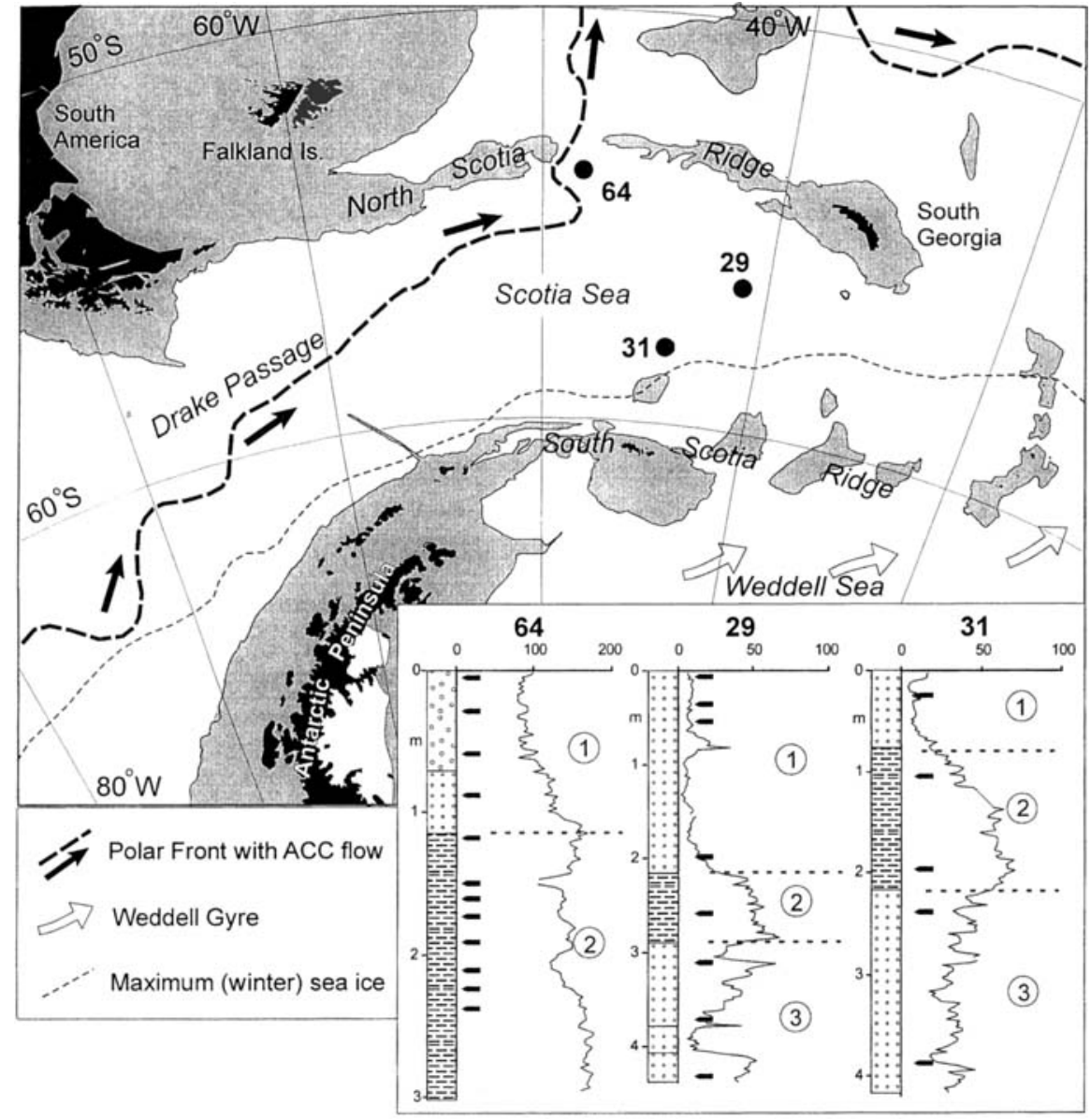

Fig. 1. Map of the Scotia Sea showing the location of cores 29,31 and 64 in relation to the axis of the Antarctic Circumpolar Current (heavy dashed line, from Orsi et al. 1995) and the northern limit of sea ice (light dashed line, from Gloersen et al 1992).

Areas shallower than $2000 \mathrm{~m}$ shaded Inset shows simplified core logs and magnetic susceptibility data (SI units x $10^{-5}$ from Pudsey \& Howe 1998). Upper and lower biosiliceous units shown in dotted ornament, with the foraminifer-bearing mud at the top of core 64 distinguished by irregular dots: dashed ornament indicates the terrigenous unit. Small black arrows are sample depths. Isotope stages (circled numbers) from data in Jordan \& Pudsey (1992), supplemented by AMS ${ }^{14} \mathrm{C}$ dates from Howe \& Pudsey (1999) and Moreton (1999).
$\left(M_{\mathrm{r}}\right)$, saturation magnetization $\left(\mathrm{M}_{\mathrm{s}}\right)$, coercive force $\left(\mathrm{B}_{\mathrm{c}}\right)$, coercivity of remanence $\left(\mathrm{B}_{\mathrm{c},}\right)$ and hysteresis loops, were measured using an automated variable field translation balance (VFTB) installed in the palaeomagnetic laboratory of the Southampton Oceanography Centre, Southampton, UK. All measurements were made on dried bulk sediment samples of a few hundred milligrams. The sediment was taken from a suite of discrete samples used for an earlier palaeomagnetic study (O'Brien 1989). The VFTB system offers the advantage of direct determination of magnetic propertics on bulk samples rather than requiring magnetic separates. Hysteresis loops, acquisition of saturation remanence $\left(\mathrm{M}_{\mathrm{rs}}\right)$ and back-ficld demagnetization of $\mathrm{M}_{\mathrm{ss}}$ were completed up to maximum fields of $0.8 \mathrm{~T}$.

\section{Results and discussion}

The magnetic properties of the samples are summarized in

Table I. Core locations, water depths and lengths.

\begin{tabular}{lcccc}
\hline Core & Latitude & Longitude & Water depth $(\mathrm{m})$ & Length $(\mathrm{m})$ \\
\hline PC29 & $56^{\circ} 25^{\prime} \mathrm{S}$ & $41^{\circ} 10^{\prime} \mathrm{W}$ & 3369 & 4.39 \\
PC31 & $58^{\circ} 03$ 'S & $44^{\circ} 20^{\prime} \mathrm{W}$ & 2745 & 4.24 \\
KC64 & $53^{\circ} 52^{\prime} \mathrm{S}$ & $48^{\circ} 20^{\circ} \mathrm{W}$ & 4304 & 3.20 \\
\hline
\end{tabular}

Table II. The measured values of the coercivity of remanence $\left(\mathrm{B}_{\mathrm{ce}}\right.$ ) are in the range $28-64 \mathrm{mT}$. Representative isothermal remanence acquisition and back-field demagnetization results from the three cores are shown in Fig. 2. All samples have broadly consistent isothermal remanence acquisition curves, with saturation being achieved at field strengths between 150 and $250 \mathrm{mT}$. This is strongly indicative of the presence of a ferrimagnetic mineral, such as titanomagnetite, as the dominant magnetic mineral, although Roberts (1995) cautions that the iron sulphide, greigite, produces similar behaviour.

The change in magnetization during heating to $700^{\circ} \mathrm{C}$ and cooling in air is illustrated by the representative thermomagnetic curves shown in Fig. 3. The majority of the heating curves have an inflexion point between $310-330^{\circ} \mathrm{C}$. This may be due to the presence of some pyrrhotite (Dekkers 1989), greigite (Roberts 1995), or titanomagnetite. This is particularly apparent in the samples from core KC64. However, the majority of the samples show a very well-defined and abrupt loss of magnetization as the Curie point of magnetite is reached near $580^{\circ} \mathrm{C}$. The decreased magnetization observed during cooling indicates that magnetite has oxidized to hematite for most of the samples. Few curves show reversible thermomagnetic behaviour. On the basis of the Curie point determinations, it seems probable that pure magnetite, rather than low-Ti titanomagnetite, is the major magnetic mineral 

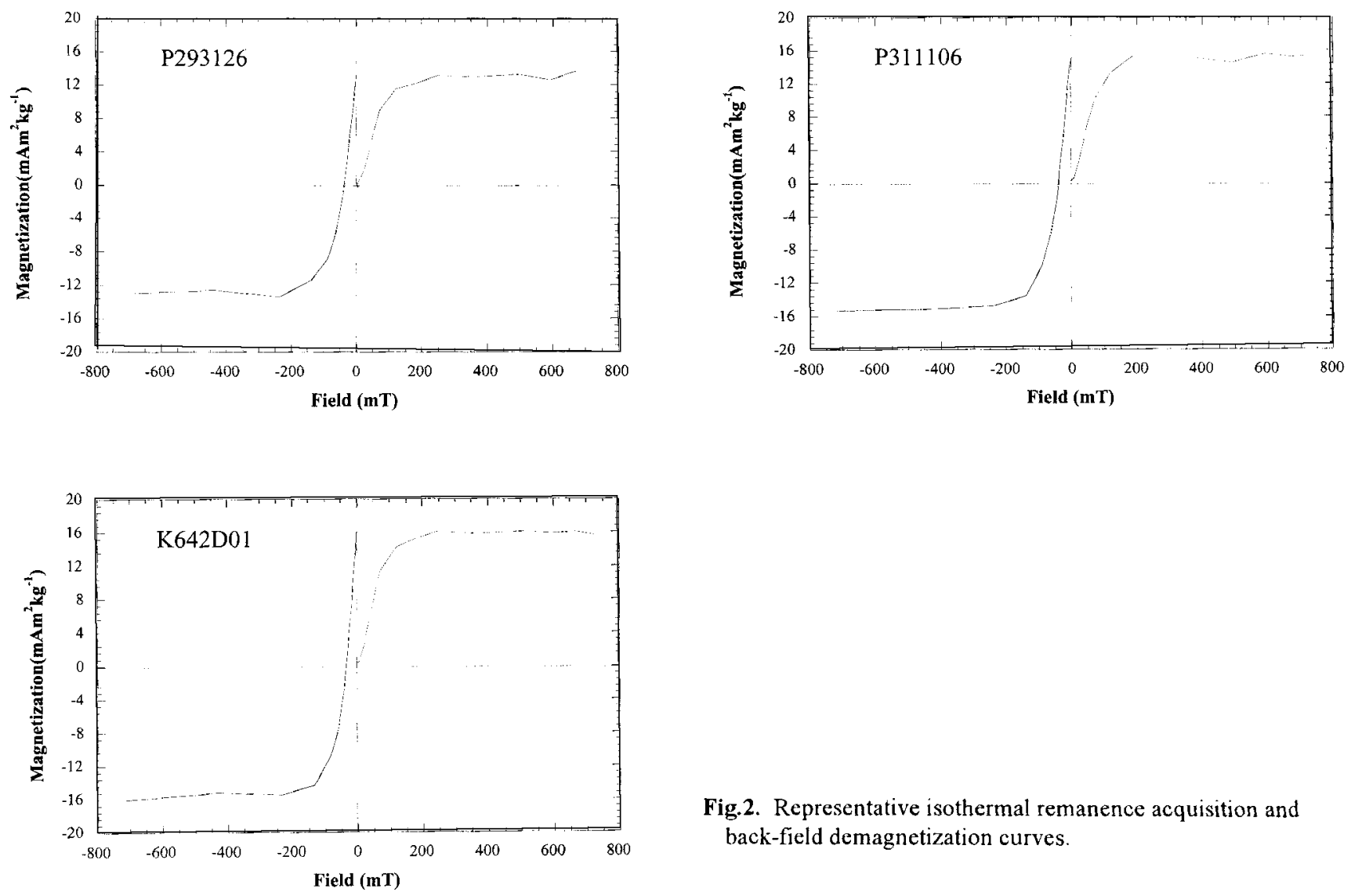

Fig.2. Representative isothermal remanence acquisition and back-field demagnetization curves.

Table II. Magnetic properties of samples used in this study.

\begin{tabular}{|c|c|c|c|c|c|c|c|c|}
\hline Sample & Lithology & $\begin{array}{l}\text { Depth } \\
\text { (mbsf) }\end{array}$ & $\mathrm{Bc}(\mathrm{mT})$ & $\operatorname{Bcr}(\mathrm{mT})$ & $\begin{array}{c}\mathrm{Mrs} \\
\left(10^{-3} \mathrm{Am}^{2} \mathrm{~kg}^{-1}\right)\end{array}$ & $\begin{array}{c}\mathrm{Ms} \\
\left(10^{-3} \mathrm{Am}^{2} \mathrm{~kg}^{-1}\right)\end{array}$ & $\mathrm{Mrs} / \mathrm{Ms}$ & $\mathrm{Bcr} / \mathrm{Bc}$ \\
\hline $\mathrm{K} 641 \times 05$ & $\mathrm{fbm}$ & 0.05 & 6.8 & 52.4 & 13.8 & 210 & 0.07 & 7.72 \\
\hline $\mathrm{K} 641 \times 29$ & $\mathrm{fbm}$ & 0.29 & 6.8 & 53.7 & 11.5 & 200 & 0.06 & 7.91 \\
\hline K641X59 & $\mathrm{fbm}$ & 0.59 & 5.1 & 38.4 & 8.2 & 165 & 0.05 & 7.53 \\
\hline K641X89 & do & 0.89 & 4.8 & 31.7 & 10.7 & 260 & 0.04 & 6.60 \\
\hline $\mathrm{k} 641 \times 119$ & $\mathrm{dbm}$ & 1.19 & 4.7 & 27.6 & 11.8 & 300 & 0.04 & 5.87 \\
\hline $\mathrm{KC} 642 \mathrm{DO} 1$ & $\mathrm{dbm}$ & 1.51 & 6.9 & 34.2 & 16.3 & 280 & 0.06 & 4.99 \\
\hline $\mathrm{KC} 642 \mathrm{D} 11$ & $\mathrm{dbm}$ & 1.61 & 6.7 & 34.3 & 16.6 & 330 & 0.05 & 5.09 \\
\hline $\mathrm{KC} 642 \mathrm{D} 24$ & $\mathrm{dbm}$ & 1.74 & 6.8 & 34.2 & 15.8 & 295 & 0.05 & 5.00 \\
\hline $\mathrm{KC} 642 \mathrm{D} 41$ & $\mathrm{dbm}$ & 1.91 & 6.9 & 34.2 & 16.1 & 310 & 0.05 & 4.99 \\
\hline KC642D61 & $\mathrm{dbm}$ & 2.11 & 6.8 & 34.2 & 19.6 & 330 & 0.06 & 5.01 \\
\hline $\mathrm{KC} 642 \mathrm{D} 74$ & $\mathrm{dbm}$ & 2.24 & 6.8 & 31.0 & 20.6 & 340 & 0.06 & 4.54 \\
\hline $\mathrm{KC} 642 \mathrm{D} 88$ & $\mathrm{dbm}$ & 2.38 & 6.8 & 34.2 & 18.4 & 370 & 0.05 & 5.04 \\
\hline TC29006 & do & 0.06 & 19.8 & 57.2 & 10.0 & 35 & 0.29 & 2.90 \\
\hline PC291036 & do & 0.36 & 19.8 & 63.9 & 7.6 & 27 & 0.28 & 3.23 \\
\hline PC291056 & do & 0.56 & 19.7 & 57.8 & 10.9 & 38 & 0.29 & 2.94 \\
\hline PC292046 & do & 2.00 & 11.8 & 46.0 & 7.6 & 65 & 0.12 & 3.90 \\
\hline PC292106 & $\mathrm{dbm}$ & 2.60 & 10.1 & 40.1 & 14.4 & 140 & 0.10 & 3.97 \\
\hline PC293006 & $\mathrm{mdo} / \mathrm{dm}$ & 3.11 & 9.6 & 40.1 & 11.8 & 115 & 0.10 & 4.18 \\
\hline PC293066 & $\mathrm{mdo} / \mathrm{d} m$ & 3.71 & 13.3 & 49.0 & 8.6 & 55 & 0.16 & 3.68 \\
\hline PC293126 & $\mathrm{dm}$ & 4.31 & 9.6 & 39.8 & 13.2 & 130 & 0.10 & 4.15 \\
\hline PC311026 & do & 0.26 & 19.6 & 48.0 & 5.9 & 27 & 0.22 & 2.45 \\
\hline PC311106 & $\mathrm{dm}$ & 1.06 & 12.0 & 40.0 & 15.3 & 130 & 0.12 & 3.33 \\
\hline PC312066 & $\mathrm{dm}$ & 2.00 & 11.1 & 40.0 & 17.5 & 160 & 0.11 & 3.60 \\
\hline PC312106 & $\mathrm{mdo} / \mathrm{dm}$ & 2.40 & 12.0 & 38.0 & 11.1 & 90 & 0.12 & 3.17 \\
\hline PC313105 & $\mathrm{mdo} / \mathrm{dm}$ & 3.89 & 15.0 & 57.9 & 13.7 & 75 & 0.18 & 3.86 \\
\hline
\end{tabular}

Lithology codes: $\mathrm{dbm}=$ diatom-bearing mud, do $=$ diatom ooze, $\mathrm{fbm}=$ foraminifer-bearing mud, $\mathrm{mdo}=$ muddy diatom ooze, $\mathrm{dm}=\mathrm{diatom}$ mud 

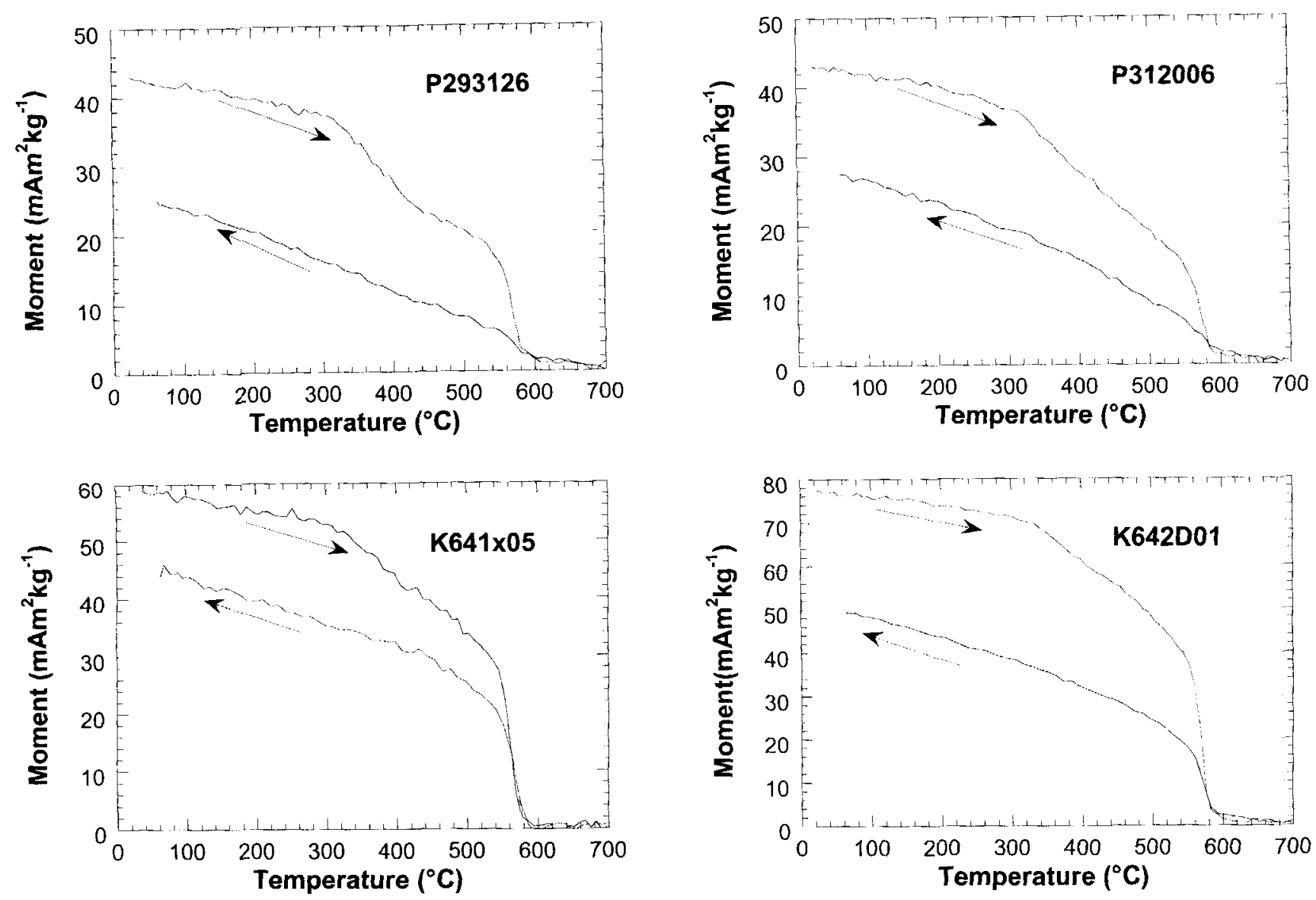

Fig.3. Typical thermomagnetic curves for heating and cooling of bulk sediment in air.

present in these sediments. This is in agreement with the visual mineralogical identification of magnetite, as described by Pudsey \& Howe (1998)

Typical hysteresis loops are shown in Fig. 4. Samples from KC64 are characterized by narrow hysteresis loops, whereas loops from PC29 and PC 31 are generally broader and more varied. The hysteresis ratio parameters recorded in Table II are confined to a range of values between 0.04 and 0.29 for the remanence ratio parameter $\mathrm{M}_{\mathrm{rs}} / \mathrm{M}_{\mathrm{s}}$ together with an average value of 4.6 for the coercivity ratio $B_{c 1} / B_{c}$. These values are consistent with the view that magnetite and/or titanomagnetite grains are present (Wasilewski 1973, Day et al. 1976, Dunlop 1986, Dunlop \& Ozdemir 1997).

Magnetic grains from cores PC29 and PC3 1 lie dominantly in the pseudo-single-domain (PSD) grain size field in a hysteresis ratio plot (Day et al. 1977), whereas predominantly multidomain (MD) type behaviour is observed for core KC64 (Fig. 5). This is in agreement with the northward-coarsening trend in bulk sediment texture of Scotia Sea cores (Pudsey \& Howe 1998). We have compared the magnetite grain diameter inferred from $B_{c}$ values (Day et al. 1977, Dunlop 1986) with median diameters from Sedigraph analyses of bulk sediment. The Sedigraph measures equivalent settling diameter assuming a grain density of $2.65 \mathrm{~g} \mathrm{cc}^{-1}$ (quartz). Allowing for the greater density of magnetite (a quartz sphere is $1.26 \mathrm{x}$ the diameter of a magnetite sphere of the same mass), the agrcement is good.

Holocene samples from cores PC29 and PC 31 have median diameters of 1.8-2 microns while glacial samples from these cores have median diameters of 2.5-4 microns, consistent with $B_{c}$ values of 19-20 and 10-15 mT respectively (Table II). Low magnetic susceptibility (Fig. 1) and the predominance of quartz in the sand fraction of these cores were explained by derivation from sedimentary and metasedimentary rocks on the east side of the Antarctic Peninsula and the islands of the South Scotia Ridge (Pudsey \& Howe 1998). In general, sediments deposited from the ACC are coarser in glacial intervals than interglacials, reflecting more vigorous $\mathrm{ACC}$ flow (Pudsey \& Howe 1998, fig. 12).

Core $\mathrm{KC} 64$ is coarser throughout, reflecting its proximity to the $\mathrm{ACC}$ axis (Fig. 1). Holocene median diameters range from 8-16 microns and glacial values are 7-10 microns, again consistent with $B$ values of $1.5-2.4$ and less than $1.2 \mathrm{mT}$, respectively; the grain size of Holocene samples shows considerable scatter by either technique. Entrainment of terrigenous detritus from the Antarctic Peninsula and southernmost South America was invoked by Pudsey \& Howe (1998) to explain high magnetite susceptibility and common volcanic lithic grains in this core. The coarse values of 

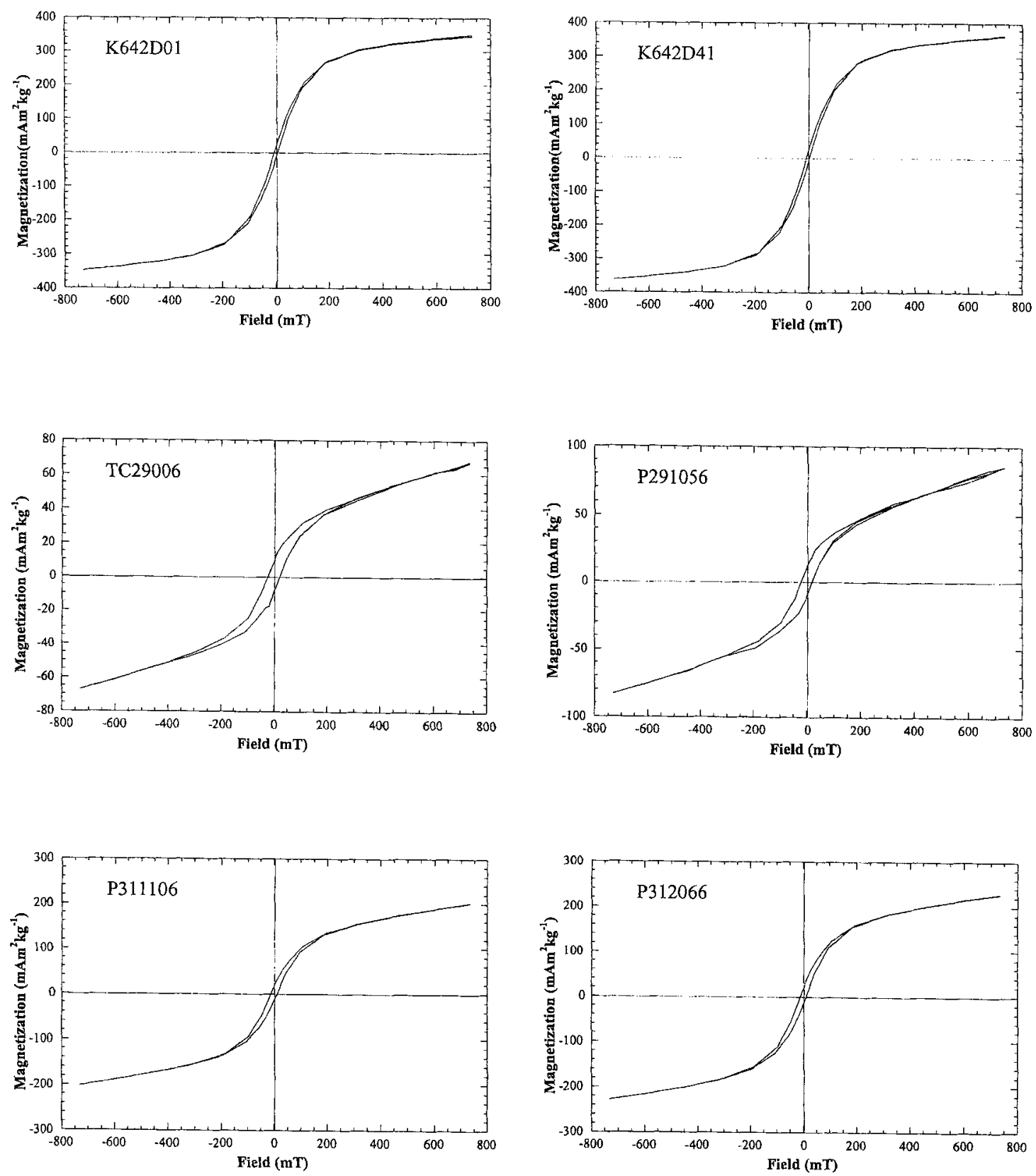

Fig.4. Representative hysteresis loop measurements demonstrating the narrow loops that characterize the northern Scotia Sea sediments of core 64 compared to the slightly broader loops of cores 29 and 31 (Note: sample TC29006 is from the trigger core of PC29).

Holocene grain size at this site (see also Howe \& Pudsey 1999 , fig. 8) are not fully understood; they cannot be attributed to localized input of ice-rafted material, since the ice-rafted debris content of core KC64 is very low (O'Cofaigh et al. unpublished data).

\section{Conclusions}

Magnetic properties investigated in this study of pelagic sediments from three Scotia Sea cores reveal the dominance of fine-grained magnetite as the remanence carrier. It is likely that this is detrital in origin, as biogenic magnetite, if present, would yield magnetic parameter data closer to SD hysteresis values than those reported in this study. The Upper Quaternary sediments from the northern and central Scotia Sea have similar magnetic parameter values which reflect currentcontrolled contourite deposition of particles with uniform size and absence of significant post-depositional diagenetic alteration. These conclusions concerning the magnetic mineralogy are compatible with earlier sedimentological inferences that a fine fraction terrigenous component is transported by the Antarctic Circumpolar Current to sites in 


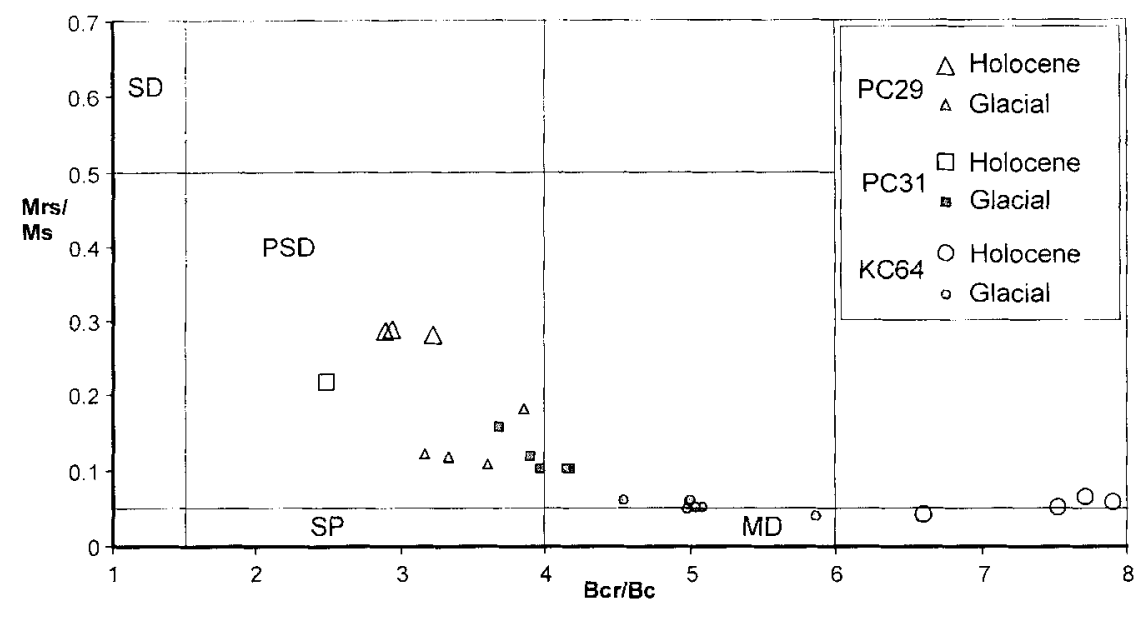

Fig.5. Hysteresis ratio plot after Day et al. (1977). SD = single domain, PSD = pseudosingle-domain, $\mathrm{MD}=$ multidomain, and $\mathrm{SP}=$ superparamagnetic particles. Holocene refers to stage 1 on core logs on Fig. 1, glacial refers to stages 2 and 3 . the Scotia Sea. This work demonstrates the potential utility of magnetic parameters as proxies for particle size and hence the strength of palaeocurrent flow; unlike bulk sediment measurements, they are unaffected by the presence of biogenic grains in the sample.

\section{Acknowledgements}

Dr John Foster provided initial guidance and advice on the operation of the VFTB system. We thank Dr Andrew Roberts for reviewing an early version of this manuscript. M.E. Evans and an anonymous reviewer are thanked for their helpful and constructive comments.

\section{References}

Burckle, L.H. 1981. Displaced Antarctic diatoms in the Amirante Passage. Marine Geology, 39, 39-43.

Charles, C.D. \& Fatrbanks, R.G. 1992. Evidence from Southern Ocean sediments for the effect of North Atlantic deep-water flux on climate. Nature, 335, 416-419.

DAY, R., FulleR, M.D. \& SCHmidt, V.A. 1976. Magnetic hysteresis properties of synthetic titanomagnetites. Journal of Geophysical Research, 81, 873-880.

DAY, R. FULLER, M.D. \& SCHMidT, V.A. 1977. Hysteresis properties of titanomagnetites: grain size and compositional dependence. Physics of the Earth and Planetary Interiors, 13, 260-267.

DekKers, M.J. 1989. Magnetic properties of natural pyrrhotite. II. High- and low-temperature behaviour of $J_{i s}$ and TRM as a function of grain size. Physics of the Earth and Planetary Interiors, 57, 266-283.

Dunlop, D.J. 1986. Hysteresis properties of magnetite and their dependence on particle size: a test of pseudo-single-domain remanence models. Journal of Geophysical Research, 91, 9569-9584.

Dunlop, D.I. \& Ozdemir, O. 1997. Rock magnetism: fundamentals and frontiers. Cambridge: Cambridge University Press, 573 pp.

Frank, M., Gersonde, R., Rutgers Van Der LoefF, M., Kuhn, G. \& Mangini, A. 1996. Late Quaternary sediment dating and quantification of lateral sediment redistribution applying ${ }^{230} \mathrm{Th}_{e x}:$ a study from the eastern Atlantic sector of the Southern Ocean. Geologische Rundschat, 85, 554-566.
Gloersen, P., Campeell, W.J., Cavalieri, D. J., Comiso, J.C., Parkinson, C.L. \& Zwally, H.J. 1992. Arctic and Antarctic sea ice, 1978-1987. satellite passive microwave observations and analysis. NASA SP 511. Washington, DC: National Aeronautics \& Space Administration, $290 \mathrm{pp}$

Howe, J.A \& Pudsey, C.J. 1999. Antarctic Circumpolar Deepwater a Quaternary palaeoflow record from the northern Scotia Sea, South Atlantic Ocean. Journal of Sedimentary Research, 69, 847-861.

JoRdAa, R.W. \& Pudsey, C.J. 1992. High-resolution diatom stratigraphy of Quaternary sediments from the Scotia Sea. Marine Micropaleontology, 19, 201-237.

Moreton, S.G. 1999. Quaternary tephrochronalogy of the Scotia Sea and Bellingshatisen Sea, Antartica. PhD thesis, Cheltenham \& Gloucester CHE, $164 \mathrm{pp}$. [Unpublished.]

Moreton, S.G. \& SMellie, J.L. 1998. Identification and correlation of distal tephra layers in deep sea cores, Scotia Sea, Antarctica. Annals of Glaciology, 27, 285-289.

O'BRIEN, P.D. 1989. The magnetostratigraphy of marine sediments from Jane Basin, southeast of the South Orkney Microcontinent, Antarctica. PhD thesis, University of Southampton, $300 \mathrm{pp}$. [Unpublished]

Orsi, A.H., Whitworth III, T. \& Nowlin JR, W.D. 1995. On the meridional extent and fronts of the Antarctic Circumpolar Current. Deep-Sea Research, 42, 641-673

Pudsey, C.J. 1992. Late Quaternary changes in Antarctic Bottom Water velocity inferred from sediment grain size in the northern Weddell Sea. Marine Geology, 107, 9-33.

Pudsey, C.J. \& Howe, J.A. 1998. Quaternary history of the Antarctic Circumpolar Current: evidence from the Scotia Sea. Marine Geology, 148, 83-112.

Roserts, A.P. 1995. Magnetic properties of sedimentary greigite $\left(\mathrm{Fe}_{3} \mathrm{~S}_{4}\right)$. Earth and Planetary Science Letters, 134, 227-236.

Sagnotti, L., Florindo, F., Verosub, K.L., Wilson, G.S. \& Roberts, A.P. 1998. Environmental magnetic record of Antarctic palaeoclimate from Eocene/Oligocene glaciomarine sediments, Victoria Land Basin. Geophysical Journal International, 134, 653-662.

Stoner,J.S., Channell, J.E.T. \& Hillaire-Marcel, C. 1995. Magnetic properties of deep-sea sediments off southwest Greenland: Evidence for major differences between the last two deglaciations. Geology, 23, 241-244.

W Asilewski, P.J. 1973. Magnetic hysteresis in natural materials. Earth and Planetary Science Letters, 20, 67-72 